\title{
The Outrageous Hunters: Does Headhunting Violate Business Standards?
}

\section{By Andreas Maurer}

Suggested Citation: Andreas Maurer, The Outrageous Hunters: Does Headhunting Violate Business Standards?, 2 German Law Journal (2001), available at http://www.germanlawjournal.com/index.php?pageID=11\&artID=105 [1] During the last few years the German courts have had to face several cases in which companies - especially from the IT-sector - filed lawsuits against "headhunters." "Headhunters" in this context are (usually) executive consultants who try to poach personnel from other companies by simply calling them and asking whether or not they want to change companies. Since skilled and qualified workers and employees are desperately but often unsuccessfully searched by innumerable German companies on the domestic and most recently also the European and international job-market(1), the methods of poaching have reached and sometimes crossed the borders of unfair practices. The courts faced with these cases had to draw these borders, a process this article attempts to outline.

[2] The facts in the various cases look quite similar: The headhunter either calls a company - sometimes pretending to be a potential customer, other times just utilizing their dialog partner's goodwill and naïveté - to find out who the specialized and therefore interesting employees are and then calls those people or he/she calls those people directly to offer them better paid and/or more interesting jobs in other companies. Normally the searching company will have engaged the headhunter.

[3] In such cases, the courts are confronted with an area of conflict between constitutionally protected professional freedom (Berufsfreiheit - Art 12 Basic Law) and the necessity of protecting companies against threats to their ongoing viability, especially in terms of inciting important employees to leave the company resulting in the loss of know-how and manpower.(2)

[4] Several companies that were targeted or victimized by "headhunter-attacks" have filed lawsuits against the perpetrator-headhunters in order to force them to refrain from contacting their company and their employees. The question the courts had to face was whether these headhunting-attacks were violative of good business standards pursuant to section 1 of the German Unfair Competition Act (Gesetz gegen den unlauteren Wettbewerb - UWG). The Federal Court of Justice (Bundesgerichtshof) has consistently held that poaching was generally permissible. Section 1 of the UWG could only be applied to prohibit headhunting when additional, objectionable facts are involved. Such objectionable facts could especially be seen in tempting an employee to breach an existing contract or the act of poaching a competitor's professional or managerial talent in order to disturb a competitor's corporate operations.

[5] In the case recently before the Regional Court (Landgericht) Heilbronn,(3) the defendant headhunter had called an employee to entice her away from her company. As no temptation to breach of contract was recognizable in the case, it was disputable whether the action taken by the defendant constituted another violation of good business conduct. The Court found three circumstances to be objectionable: (1) The headhunter had called the employee on the customer-line; (2) There was no personal relationship between the headhunter and the employee; and (3) The defendant headhunter had asked the contacted employee to hand out his/her name, address and telephone-number to other potentially interested employees in the targeted company. The Landgericht found these circumstances to constitute a "grave disturbance of the company's working process that subverts the loyalty to the employer."(4)

[6] In another case(5) the Higher Regional Court (Oberlandesgericht) Stuttgart had to decide whether it was a violation of good business conduct, pursuant to Section 1 of the UWG, when the headhunter calls the company's operator and asks her to connect him with "the most competent employee for sales and distribution of network solutions." In this case, the operator met the headhunter's request and connected him with an employee who then gave his private phone-number to the headhunter. The headhunter later called this employee, two times, at the employee's home, but ultimately failed to "poach" the employee. In this case, as in the case of the Landgericht Heilbronn, it could not be concluded that the headhunter had tempted the employee to violate contractual obligations or to breach the contract in any way. Once again, other unethical facts had to be discerned by the Court in order to grant relief. The Oberlandesgericht found objectionable the fact that the headhunter had utilized the company's infrastructure by calling the employee. The Judges found this to be a "disturbance of the enterprise's integrity by unitizing its infrastructure." The judges also ruled that, consistent with older jurisprudence from the 1960s and 1970s, the intrusion into the company's infrastructural facilities and building was objectionable. They held that today's modern communication media granted even greater access to protected spheres of business and privacy and that a telephone call was therefore comparable to a headhunter's personal visit. Pursuant to this analysis, the phone call at the center of this case was considered unethical pursuant to Section 1 of the UWG.

[7] It is out of the question that headhunting and the danger for companies that emanates from that practice is both a problem and an opportunity for modern job markets. On the one hand, it strengthens competition among companies and - as employers will want to bind their employees to their companies - therefore creates the potential for higher wages and in some states probably other benefits like health insurance and other social merits for the employees. On 
the other hand, it certainly weakens companies that are especially dependent upon specific, specialized and uniquely skilled employees. That may especially be the case for small and medium-seized enterprises. While these companies certainly need to be protected, the ruling of the Oberlandesgericht Stuttgart definitely goes too far. A "disturbance of the integrity of the enterprise" can hardly be seen in one single telephone call. Furthermore, the corporal intrusion into a company's buildings cannot be logically compared to a phone-call or an email.

[8] Section 1 of the UWG is supposed to protect companies from unfair competition, but it is not meant to inhibit permissible and desired competition. It is certainly difficult to draw a line between permissible competition that benefits not only employees, and unfair competition that puts enterprises and therefore jobs at high risk. But, as the Federal Court of Justice has started to outline in its jurisprudence, (recognizing that certain practices like the temptation to breach a contract or the willful damage to a competitor qualify as unethical and actionable) the line must be found somewhere between the competing interests and not exclusively on the one or the other side.

(1) Even the German state supports the companies' efforts to recruit skilled and specialized foreign IT-personnel with the German "Green Card" regulations (Verordnung ueber die Arbeitsgenehmigung fuer hoch qualifizierte ausländische Fachkräfte der Informations- und Kommunikationstechnologie published on 11 July 2000 [BUNDESGESETZBLATT I 2000, p. 1146 seq.]; Verordnung über Aufenthaltserlaubnisse fuer hoch qualifizierte auslaendische Fachkräfte der Informations- und Kommunikationstechnologie published on 11 July 2000 [BUNDESGESETZBLATT I 2000 p. 1176 seq.]). With this "Green Card" foreign IT-specialists can receive a temporary employment permit.

(2) Reufels, Neue Fragen der wettbewerbsrechtlichen Beurteilung von "Headhunting," GEWERBLICHER RECHTSSCHUTZ UND URHEBERRECHT, p. 214, 215 (2001).

(3) Landgericht (Regional Court) Heilbronn, Decision of 21/05/1999, reg. no.: $1 \mathrm{KfH}$ 152/99, published in: NEUE JURISTISCHE WOCHENSCHRIFT-RECHTSPRECHUNGS REPORT, 1999, p. 1567 et seq; the decision can also be found under: http://www.jupc.de/rechtspr/20010045.htm (last visited 18 October 2001).

(4) Id at p. 1568.

(5) Oberlandesgericht (Higher Regional Court) Stuttgart, Decision of 17 December 1999, reg.no.: 2 U 133/99, published in BETRIEBS BERATER 2000, p. 633-635. 